\title{
Reflexions a propòsit de l'«Anecdotari artanenc» de Rafel Ginard
}

\author{
Jaume Guiscafrè Danús \\ Universitat de les Illes Balears \\ jaume.guiscafre@uib.cat
}

\begin{abstract}
RESUM
Aquest article pretén aportar algunes reflexions sobre la naturalesa de l'anècdota, entesa com a gènere narratiu autònom. Les dificultats o la impossibilitat de catalogar molts dels relats continguts en l' «Anecdotari artanenc», manuscrit i inèdit, del folklorista Rafel Ginard són, de fet, l'origen d'aquestes reflexions. La primera part del treball està dedicada a la descripció del manuscrit i a la discussió dels problemes que suscita la catalogació dels relats que l'integren. Segueix a continuació una anàlisi comparativa de dotze propostes de definició o de descripció de l'anècdota que han fet tants altres autors o folkloristes i de setze exemples que me'n proporcionaren els meus alumnes de l'assignatura Teoria del Folklore. La conclusió final és que, tot $i$ que té molts de punts de contacte amb la llegenda, el relat d'experiència personal $i$, sobretot, amb l'acudit, l'anècdota se'n diferencia perquè sempre té un propòsit admiratiu o laudatori respecte del protagonista, que és una persona real o una celebritat, i perquè constitueix una mena de precedent d'autoritat amb vista a la resolució de la situació vivencial $i$ comunicativa que la suscita.
\end{abstract}

PARAUles CLAU

Anècdota, acudit, gèneres folklòrics narratius, teoria del folklore, classificació

\begin{abstract}
This article aims to provide some thoughts on the nature of the anecdote, defined as an autonomous narrative genre. The difficulties or the impossibility to catalogue many of the stories contained in the "Anecdotari artanenc", an unpublished manuscript by the folklorist Rafael Ginard, are, in fact, the origin of these reflections. The first part of the work is devoted to the description of the manuscript and to the discussion of the issues raised by the classification of the stories that make up the manuscript. Then follows a comparative analysis of twelve proposed definitions or descriptions of the anecdote by different authors and folklorists, and of sixteen examples provided by the students in my Folklore Theory course. The final conclusion is that, despite the anecdote has many points of contact with the legend, the story of personal experience and, above all, the joke, it differs widely from these genres because it always has a laudatory or admiring purpose toward the main character, who is a real person or a celebrity, and because it works as a kind of precedent authority in order to resolve the existential and communicative situation that provokes it.
\end{abstract}

KEYWORDS

Anecdote, joke, folk narrative genres, folklore theory, classification 


\section{1. $L^{\prime} « A n e c d o t a r i$ artanenc $c{ }^{1}$}

Entre els materials del folklorista Rafel Ginard i Bauçà (Sant Joan, Mallorca, I899 Artà, Mallorca, I976) que hi ha dipositats a l'Arxiu Provincial del Tercer Orde Regular de la Porciúncula, a Palma, es conserven dos quaderns inèdits manuscrits, titulats «Anecdotari artanenc» $\mathrm{i}$ «Anecdotari artanenc. Volum II». El primer, datat a Artà entre el 28 de juliol i l'II de setembre del I932, conté quaranta-cinc textos numerats, seguits d'un epíleg dividit en sis apartats. El segon, datat també a Artà l'i d'octubre del I932, conté vuit textos numerats, el segon dels quals és incomplet. Aquests cinquanta-tres textos inclouen un total de vuitanta-quatre relats anecdòtics. Ginard, que ha passat a la història de la folklorística catalana pel seu Cançoner popular de Mallorca, ${ }^{2}$ deu ser el primer folklorista català que es proposa dur a terme un recull monogràfic d'anècdotes, tot i que el propòsit que el mou té més relació, com veurem, amb la pràctica de l'escriptura creativa que no amb la pràctica de la folklorística.

En l'epíleg esmentat, Ginard hi fa tot un seguit d'observacions i de reflexions, inconcluses i que s'han de prendre, doncs, com a provisionals, sobre l'anècdota. Se'n desprèn que la concep com una narració humorística que tracta de "personatges cèlebres pel seu humor, per la seva agudesa o per la seva graciosa beneiteria» els fets o les dites dels quals són «dignes de perpetuar-se per fer brollar, a l'hora oportuna, la font sagrada del riure faceciós» («Epíleg» III). Així mateix, en destaca dos aspectes que no en són definidors però que ho paga comentar. D’una banda, segons Ginard, l'anècdota desperta l'interès dels caràcters o de les persones pessimistes («Epíleg» IV i V) i, a propòsit d'aquesta observació, cal fer notar que al text original hi ha una ambigüitat de mal resoldre, perquè tot i que el folklorista mallorquí es retrati a ell mateix quan reflexiona sobre la relació entre humor i pessimisme, també sembla donar entenent que es refereix als usuaris, als cultivadors, de les anècdotes que ha recollit $i$, tal vegada, també a les persones que en són protagonistes. D'altra banda, Ginard insisteix en la idea que l'anècdota ha d'estar redactada de manera graciosa; i si en posa en relleu aquest aspecte és perquè, si bé inicialment només tenia la intenció d'«inventariar les anècdotes gracioses que corren per Artà», va pensar que «seria més interessant la col-lecció si hi intercalàvem la silueta física i moral del personatge a què fan referència les coses de riure» («Epíleg» III) i aleshores, segons confessa ell mateix, es va prendre la redacció d'aquest recull d'anècdotes «a manera de gimnàsia intel-lectual i estilística», ja que «a l'escriptor li és útil exercitar-se en els diferents estils per adquirir més agilitat i provar els diferents registres d'expressió que té l'orgue del llenguatge humà» («Epíleg»VI).

En aquest recull, doncs, hi combina la narració dels fets pròpiament dits amb la descripció i la caracterització dels personatges que en són protagonistes, tots ells prou coneguts al poble al primer terç del segle xx; i alguns, encara avui dia, perquè hi ha gent que en conserva la memòria - jo fins i tot vaig tenir la sort de conèixer-ne un i de tenir-hi relació.

I. Aquest article s'emmarca en una línia de recerca sobre literatura popular catalana que ha rebut finançament del Ministeri d'Economia i Competitivitat a través del projecte d'R+D FFI2OI2-31808.

2. Sobre la vida i l'obra d'aquest folklorista mallorquí és imprescindible consultar Rosselló (I999). 


\section{La catalogació dels materials}

De les vuitanta-quatre anècdotes que conté el manuscrit, només onze es poden catalogar sense problemes d'acord amb Uther (2004) i es poden adscriure adequadament, doncs, als set tipus ATU següents: I337 A Farmer Visits the City (I versió), ${ }_{1567 \mathrm{H}}$ The Big and the Small Fish (I versió), I678** First Time in Church (I versió), I698J The Misunderstood Greeting (2 versions), I704 Anecdotes about Absurdly Stingy Persons (4 versions), I706 Anecdotes about Drunkards (I versió) i I806* Tales of Confessions (I versió). D’altra banda, hi ha cinc versions més que es podrien adscriure amb reserves a altres tres tipus: 1589 The Lawyer's Dog Steals Meat (I), I706 Anecdotes about Drunkards (I) i I864 Anecdotes about Madmen (3). La resta de relats, en principi, no tenen correspondència amb cap dels tipus que preveu l'índex internacional.

A l'efecte de l'estudi d'aquest corpus inèdit i en relació amb la catalogació de les anècdotes, crec que pot ser operatiu establir-hi, com a mínim, quatre categories per poder donar compte d'algunes dinàmiques que hi estan relacionades i de com en poden afectar la categorització i la catalogació.

La primera inclou aquelles contarelles «tradicionals» que cristal-litzen a l'entorn d'una persona real i coneguda perquè els fets narrats s'adiuen amb la que el narrador pensa que és la seva idiosincràsia o la seva personalitat. És el cas de la versió que correspon a ATU I567H (I, XXI): ${ }^{3}$

Dos que dinen a la fonda Randa o ca n'Armengol. Sospit si el manescal Moll fou un dels que intervingueren. Tragueren dos peixos: un gros i un petit. Ningú vol prendre primer amb l'esperança de que l'altre —el qui prenga davant- se'n durà el peix petit. A aqueixa intenció, la s'endevinen mútuament però no poren dir-s'ho i han d'anar de circumloquis, replens interiorment d'una secreta malícia. Tots dos, implacables, miren el peix gros. Tots dos el volen i fan filigranes de compliments per convèncer-se un a l'altre del que ni un ni l'altre volen fer: pendre davant. No poden increpar-se perquè ambdós porten la mateixa intenció i són moguts per una idèntica golafreria i egoisme. Tots els compliments són un disfrès del seu perfet egoisme. L'escena s'allarga, tràgicament; el peix se refreda. Un, finalment, fent el cor fort, se decideix i enforca el peix gros. Decepció enorme de l'altre. L'increpa de mal educat, sortint pels furs de la bona criança.

—El qui pren primer, pren el petit! Això no és educació ni res que s’hi assembli...

El qui té ja el peix gros, segur ja d'empassar-lo-se, li replica, rient per sota el nas:

-I si tu haguessis pres davant, quin peix te n'hauries duit?

—iEl petit!

-Doncs, és el que t'he deixat. No l'has pres tot d'una, però així mateix serà el teu. Te queixes de que t'hagi deixat allò mateix que tu hauries pres! No ho entenc!

3. Especific, entre parèntesis, el nombre del quadern en què figura el relat i la numeració que hi duu. 
Massa que ho entenia...

Encara s'hi podria afegir aqueixa subtilesa. Figurar que l'amo del peix gros digui:

- Jo ho pressentia, que tu hauries pres el petit i, per delicadesa, el te vaig deixar. Ademés, vaig consentir a passar per golafre just perquè no creguessis que jo t'hi considerava i t'ho hauries pogut pensar si jo hagués deixat per tu el peix gros. Tu interiorment hagueres dit que jo malpensava de tu...

Aquesta versió em sembla interessant per dos motius: en primer lloc, perquè hi és ben patent la reelaboració — inacabada—a què Ginard sotmet el relat oral de l'informant i que és ben manifesta en la descripció de les estratègies no verbalitzades dels dos personatges, que té com a conseqüència la demora de la narració, i en el fragment de diàleg que preveu que podria incorporar-hi en la redacció definitiva del relat; en segon lloc, perquè el narrador no pot determinar amb certesa qui eren les dues persones que dinaven a la fonda (només sospita que una era el manescal Moll), amb la qual cosa l'únic ancoratge amb la realitat immediata és la localització — també dubtosa, per cert— de l'acció en una fonda del poble d'Artà.

Jaume Guiscafrè Llull, de 8I anys i natural d'Artà, on ha viscut sempre, em va contar, a l'estiu del 20I2, aquest mateix relat, però no va dubtar ni un moment a l'hora d'atribuir-ne el protagonisme al manescal Moll i al seu germà, que era capellà:

I un dia dinava [el manescal Moll] amb so seu germà, capellà, i... ell va acabar sa primeria primer. Hi havia... i de segon hi havia dos peixos, un perhom, o siga dos peixos, però n'hi havia un de petit i un de gros. I ell va acabar primer, 'gafa es peix gros i... i es capellà li diu:

—Això no està bé!

Diu:

— ¿Què vol dir no està bé?

Diu:

-No - diu-. Es qui 'gafa primer... No hauries d'haver 'gafat es gros. ¡Això és falta d'educació!

Diu:

-I tu, si haguessis 'gafat, quin hauries 'gafat?

Diu:

-iJo es petit!

Diu:

-Idoi, tens es que volies... Què has d'anar a cercar? Tens es que volies.

A parer meu, aquesta altra versió és una bona mostra del procés de cristallització a què m'he referit més amunt: els vuitanta anys que separen les dues versions no han passat en va, i el que el I932 era una contarella el 2012 ja és una anècdota. Això, naturalment, no exclou la possibilitat que encara es puguin recollir altres versions d'aquesta història en forma de contarella ni que el mateix narrador no la pugui actualitzar en forma de contarella en una altra situació comunicativa o davant un auditori diferent. I és que els narradors competents coneixen la con- 
figuració retòrica pròpia de cada gènere etnopoètic i, com que els arguments no estan indissolublement lligats a cap gènere concret, poden actualitzar una història determinada amb una configuració genèrica o una altra en funció de les particularitats contextuals que defineixen la performance i amb l'ajut de les estratègies retòriques que hi estan associades (Bennett I988: 25-26).

Aquest mateix procés d'adherència d'un relat o d'un cicle de relats a una persona real o a una personalitat és habitual que es doni també amb la llegenda i amb l'acudit. En el cas de la primera, l'adherència hi pot tenir un propòsit enaltidor o laudatori - pensem en les relatives al rei Jaume I, a sant Vicent Ferrer o a Joan de Serrallonga- o, contràriament, un propòsit vilipendiador — per exemple, les relatives a Ramon Saforteza, segon comte de Santa Maria de Formiguera. En el cas de l'acudit, en canvi, l'adherència hi té un propòsit clarament ridiculitzador: n'és un bon exemple el cicle relacionat amb Fernando Morán, que va ser el ministre espanyol d'Afers Estrangers entre el 1982 i el 1985.4

Una segona categoria de relats inclou els que es poden catalogar sota algun tipus ATU perquè la descripció que se'n fa no és gaire precisa o perquè es tracta de tipus miscel-lanis. És el cas dels quatre que es poden adscriure a ATU I7O4 o el de l'anècdota que transcric a continuació (I, XXXVII), que té com a protagonista el capellà Ranxer i que cal considerar com una versió d'ATU I806*:

Ell feia com a de vicari, un temps, a Cala Ratjada. Els diumenges se confessaven molts. Allò era un abús, tanta de confessera. I, dispost a tallar-lo, un diumenge surt al presbiteri i diu:

—Que vénguen només a confessar-se els qui tenguen pecats mortals. Els demés, no importa.

És bo de veure que ningú hi anà. Manera infal-lible d'acabar amb els abusos i excessos de fervor...

Els relats que es poden adscriure amb reserves o amb alguna dificultat a algun tipus ATU formen una categoria a part. Un bon exemple n'és l'anècdota següent (I, XVIII):

Era un any per les festes de Pasqua. Mestre Miquel s'inquero havia comprat el frit. El notari tenia una cussa que tirava al dret. I, no volgueu saber res més, se'n dugué el frit. Mestre Miquel ho sap. Crida una filla i li dóna un bòtil de vi.

-Vés a cas notari i digue-li: «Duc aquest vi per la seva cussa, que s’ha menjat el nostre frit...»

El notari se posà la mà a la butxaca i pagà el que el frit valia. Era el que mestre Miquel se proposava... Fou una manera graciosa de demanar-li el que el frit valia.

D'entrada, crec que caldria adscriure aquest relat al tipus ATU I589. L'adscripció, però, és problemàtica, perquè el relat té l'inconvenient que no acaba d'ajustar-se al model. Tot i que hi comparteix els elements fonamentals, en difereix en

4. A propòsit de la vigència d'aquests acudits, el diari El País va publicar, el 2I d'agost del I984, una carta de Julio Álvarez en què, entre d'altres, fa l'observació següent: «Mi objeción a tales chistes es que son viejos; yo, personalmente, los conozco hace años, antes de que el señor Morán fuera ministro. Eran chistes que se decían de belgas y son ancianos internacionalmente.» 
la manera com es resol el conflicte, perquè tant la descripció que fa Thompson (I993) del motiu K488 com la que fa ATU del tipus pivoten sobre la reacció, alhora intel-ligent i mesquina, de l'advocat. En la versió que acab de transcriure, en canvi, la gràcia està en la reacció elegant i plena d'ironia fina del propietari de la freixura, a la qual no pot sostreure's el notari, que no té més remei que satisfer l'import de la carn que la seva cussa havia robat.

La quarta categoria inclou els relats que no poden adscriure's a cap tipus ATU, perquè no n'hi ha cap que s'hi ajusti. Les causes per què no s'hi puguin catalogar poden ser diverses. En uns casos, perquè es tracta d'algun dels «countless jokes told in modern tradition» a què es refereix Brunvand (I998: 238), tot i que cal reconèixer que en la darrera revisió de l'índex que ha dut a terme Uther sí que se n'hi han incorporat de nous, per exemple el I69IC* Permission Misunderstood. En altres casos, perquè es tracta de relats que no han merescut l'atenció dels folkloristes pel fet que «they are not traditional in content and so afford little opportunity for the comparison of analogues» (Allen I989: 237). De vegades, perquè es tracta d'anècdotes d'abast purament local - la qual cosa no vol dir que eventualment no se'n puguin documentar versions en altres indrets. I, encara, hi ha el cas dels relats - tant fa ara que siguin anècdotes o acudits_ que basen l'eficàcia retòrica i comunicativa en un joc de paraules i que, per tant, difícilment podran entrar mai a formar part d'un catàleg internacional, perquè la textura mateixa n'impedeix la traducció i, doncs, la migració. L'anècdota següent (I, XXVIII), per exemple, que també protagonitza el manescal Moll, pivota sobre un joc de paraules que només és rendible en català:

$\mathrm{Al}$ «matadero». Un carnisser ha mort un xot malalt. Per conèixer si un animal és dolent serveix molt bé la tela, que no sé ben bé què és. La hi llevaren. Arriba en Moll. Veu aquell be sense tela i s'hi atura, s'hi atura... mentre el carnisser es desespera. I per dissimular li pregunta:

-Manescal, que no li veu la tela? És que...

I el manescal, amb un moviment sec alça el cap, li afitora la vista i, jugant amb la paraula, li clava aquesta:

- La teva tela et veig!

I li féu tirar el xot.

El joc lingüístic — sobre el qual el narrador, per cert, crida l'atenció del lector d'una manera maldestra - se centra en la paraula tela, que s'usa col-loquialment per referir-se al 'peritoneu' i que figura també en la locució veure la tela a algú, que significa 'endevinar-ne la intenció oculta'.

\section{Un repàs terminològic}

La dificultat o la impossibilitat de poder catalogar de manera adequada la gran majoria dels textos recollits i redactats de Ginard em suscità la necessitat de revisar el concepte d'anècdota i l'adequació d'aquest concepte a les categories que integren la secció de Jokes and Anecdotes de l'índex ATU. A què ens referim quan fem servir el terme anècdota? Fins a quin punt són pròpiament models d'anècdota —o d'acudit- els tipus ATU que constitueixen la secció Jokes and Anecdotes? Les preguntes no són gens gratuïtes si tenim en compte que el mateix Thompson 
(I977: 2I6-2I7) afirma sense ambigüitats que l'anècdota, com a classe de relat, no té cap mena de particularitat genèrica i la considera un gènere més aviat propi de la literatura popular escrita:

the simple anecdote refuses to take on very definite form and texture. It has its main point with which every teller may exercise his skill. There is no special virtue attached to faithfulness of text or the maintenance of an old tradition. Of whatever ultimate origin, the anecdote is likely to be handed on from century to century and from country to country between the covers of books or pamphlets, and, with rare exceptions, as apparently in Finland, submits itself and then only imperfectly to the processes of folktale tradition.

No ens ha d'estranyar, doncs, que la dificultat més gran per poder catalogar adequadament versions d'anècdotes o d'acudits amb l'índex ATU es trobi precisament en la secció mateixa dels Jokes and Anecdotes. Ho ha vist i ho ha explicat molt bé Brunvand (I998: 238):

The jokes and anecdotes section of the Type-Index also has a misleading title: no real difference between the two categories is established, and, as we have seen, the term «anecdotes» is usually applied to a subclass of personal legends. Simply «jokes» seems the best term for short, funny, fictional folktales, but only a few of the countless jokes told in modern tradition are included in the Index. This section of the Index is essentially a classification of the older European jests, or merry tales - humorous stories characterized by short, fairly simple plots and by realistic settings.

Deixant de banda molts altres termes que els estudiosos i els folkloristes associen de manera més o menys habitual a la mena de relats que ens ocupen -i que fan pensar que potser és molt més urgent la unió terminològica que no la unió política, fiscal i financera de què parlen tant els nostres governants- ${ }^{5} \mathrm{~m}$ 'he centrat només en el terme anècdota per comparar-ne dotze definicions o descripcions que, de manera implícita o explícita, n'han proposat tants altres estudiosos i que present de manera sintètica en la graella que don en annex. L'he estructurada a partir de set variables que solen entrar en joc en les definicions o les descripcions del gènere, si bé no totes hi tenen la mateixa importància ni totes hi són mai presents a la vegada: el caràcter, l'estructura, l'extensió, la tradició, la versemblança o la veridicitat del relat, els protagonistes i els fets narrats. Les variables que els autors no esmenten expressament, però que són fàcilment deduïbles del seu discurs, hi figuren entre parèntesis.

Les tres variables que tenen una menor incidència en les definicions o les descripcions són l'extensió, la tradició i la versemblança o la veridicitat del relat. Quant a la primera, els sis autors que la prenen en consideració coincideixen a remarcar-ne la brevetat. Dels cinc que en tracten la tradició, tots coincideixen —amb qualque matís - a situar l'anècdota en la tradició oral, però n'hi ha tres

5. Sense cap mena de pretensió de fer-ne una llista exhaustiva, em referesc a termes com acudit, agudesa, belief tale, fabulate, facècia, facetie, fool's novella, hero tale, jest, jocular tale, joke, memorate, merry tale, relat d'experiència viscuda, rumor, schwank, sortida, succeit, swindler novella, tall tale... 
que també la consideren pròpia de la tradició escrita. ${ }^{6}$ Respecte de la versemblança o la veridicitat del relat, els cinc que la prenen en consideració coincideixen a remarcar-ne l'ambivalència, tot i que em fa l'efecte que no sempre s'estableix de manera prou clara la diferència entre versemblança i veridicitat i crec que és essencial: versemblança significa 'qualitat de versemblant', és a dir, 'que té l'aparença de veritat' i també, més específicament, 'conformitat dels personatges i les accions amb les normes generalment acceptades i al mateix temps amb les normes específiques del gènere literari a què pertany l'obra'; veridicitat, en canvi, significa 'qualitat de verídic', això és, 'en què es diu realment el que és, la veritat'. Així, doncs, l'anècdota — com a gènere verbal que té una configuració artística determinada - ha de ser, per força, versemblant i pot tenir, a més, una certa aparença de veridicitat, però no s'hi exigeix perquè és absolutament irrellevant que els fets que s'hi narren no siguin susceptibles de documentar-se històricament.

Les quatre variables a què s'apel·la d'una manera més recurrent per definir o descriure el gènere són el caràcter (onze dels dotze autors), la naturalesa dels fets narrats (deu dels dotze), els protagonistes (nou dels dotze) i l'estructura (vuit dels dotze). A propòsit de la primera d'aquestes variables, hi ha quatre autors que destaquen el caràcter humorístic de l'anècdota; dos, en canvi, li atribueixen caràcter llegendari; uns altres dos consideren que pot tenir tant caràcter humorístic com caràcter llegendari; un en posa en relleu el caràcter autònom; un altre, el caràcter didàctic, i, finalment, només un adscriu l'anècdota als relats d'experiència real, amb la qual cosa coincideix, com veurem més avall, amb la que diria que és la percepció que majoritàriament tenen els usuaris reals no iniciats o no especialitzats en folklorística. Respecte de la segona variable, hi ha molta diversitat en la consideració de quina mena de fets són propis dels relats anecdòtics: n'hi ha que consideren que han de constituir motius o tipus tradicionals i d'altres que opinen que han de ser originals i no estereotipats, no tradicionals, doncs; n'hi ha que consideren que han de ser dignes de ser narrats i d'altres que n'hi ha prou que s'atribueixin a personatges coneguts... Quant als protagonistes dels relats, dos es limiten a dir que poden ser tant humans com animals; els altres set coincideixen a remarcar que són persones, si bé les especificacions respecte de quina mena de persones varien molt d'un a l'altre: ocurrents, conegudes, reals, personalitats, celebritats, grups... Que hagin de ser persones conegudes em sembla imprecís (de qui han de ser conegudes? Del narrador? De l'auditori? Del petit grup?) i seria més aviat partidari de parlar de persones reals o de personalitats o celebritats, si escau, l'existència de les quals pot demostrar-se documentalment, i d'evitar el substantiu personatges, que sempre és ambigu. I, finalment, respecte de la quarta variable, l'estructura, sis dels vuit autors que la tenen present en remarquen el caràcter uniepisòdic, i n'hi ha tres que en destaquen la resolució verbal del conflicte, una apreciació que em sembla molt pertinent perquè defineix el límit que separa l'anècdota de la contarella o de la llegenda i que l'acosta, en canvi, a l'acudit.

6. Més que de tradició, jo seria partidari d'usar el terme mitjà (oral o escrit), atès que la tradicionalitat no és una característica exigible a cap ítem folklòric. 


\section{Un exercici de classe}

A diferència del que passa amb molts termes tècnics propis de la folklorística, que tenen un abast semàntic molt concret i especialitzat i que usam només els iniciats o els folkloristes, el terme anècdota es fa servir de manera molt habitual per designar una categoria de relats que circulen oralment, dels quals són usuaris o protagonistes habituals els parlants mateixos, i l'abast que li donen difereix bastant del que li donen molts especialistes, que com acabam de veure tampoc no s'acaben de posar d'acord.

A propòsit d'aquesta divergència en l'abast semàntic que se sol donar al terme, vaig comanar la tasca següent als meus alumnes de l'assignatura Teoria del Folklore: a la sessió del ı6 d'octubre del 20 2 2 els vaig demanar que a la sessió següent, la del I8 d'octubre, em presentassin, per escrit, un acudit, una llegenda i una anècdota, amb l'advertiment previ que no hi pensassin gaire ni reflexionassin sobre la configuració retòrica d'aquests tres gèneres. Érem tot just a la quarta setmana de curs i encara no havíem tractat dels gèneres a classe: la «virginitat» dels informants-alumnes, doncs, estava assegurada. Si els vaig demanar de manera explícita que em proporcionassin un exemple de cada un d'aquests tres gèneres és perquè una bona part dels folkloristes que hi han reflexionat afirmen que l'anècdota bascula entre la llegenda i l'acudit i m'interessava constatar fins a quin punt aquest fet es podia reflectir en les mostres. En resumesc els resultats a continuació.

De les setze aportacions que els alumnes consideren com a exemple d'anècdota que em varen proporcionar, només una cau totalment fora del que - sigui com sigui que la definim - catalogaríem com a anècdota, perquè es tracta d'una tradició explicativa. Els altres quinze textos els hauríem de distribuir d'aquesta manera, si seguíem per exemple — i jo ho faig sovint- Oriol (2002: 80-85): set relats d'experiència personal, sis succeïts, una anècdota i un acudit. Dels quinze alumnes que varen fer aportacions aprofitables, n'hi ha sis que posen en relleu d'una manera o altra la comicitat aparentment intrínseca al gènere i una que en destaca la veridicitat. Una vegada que vaig haver analitzat els textos, els vaig demanar quin criteri havien seguit per assignar els relats a cada gènere: l'única alumna que m'havia proporcionat un exemple d'anècdota segons la definició que en fa Oriol —un exemple «de manual», per entendre'ns - va reconèixer que havia contravingut les meves indicacions, que havia cercat la definició del terme en un diccionari i que llavors havia cercat un text que s'hi ajustàs.

Els resultats, doncs, són prou eloqüents i diria que, fins i tot, previsibles, perquè concorden amb l'abast semàntic que de manera habitual o col-loquial se sol donar al terme anècdota: un relat breu, de caràcter humorístic, que exposa uns fets que ha protagonitzat algú molt pròxim al narrador o dels quals el narrador mateix ha estat protagonista o testimoni directe. ${ }^{7}$

Per il-lustrar la diversitat dels exemples que em varen proporcionar els alumnes i les fluctuacions que els poden afectar i que sovint fan molt difícil establir límits genèrics precisos entre els relats, en transcriuré tres i en comentaré els aspec-

7. Aquest és l'abast que també s'intueix en el fragment d'una conversa que varen mantenir dues infermeres, a principi d'octubre del 20I2, en un passadís del mòdul d'urologia de l'hospital universitari Son Espases de Palma: - ¿Te cuento una anécdota? - ¿La de las bandejas? —Ah, ¿ya lo sabes? — Sí, pero no lo digo porque no me gusta reírme de los demás. Yo soy muy discreta. - Es que ha sido muy divertido. 
tes que em semblen més significatius. El primer, que va aportar Maria Company, seria un bon exemple de relat d'experiència personal que, tot i que no l'hi puguem considerar, s'acosta a l'acudit:

Anys enrera, els meus pares i jo, anàvem tots els divendres a sopar a Petra, a ca sa padrina. El sopar no era sempre el mateix, però el context, sí. Sopàvem a les 20:30 h, sa padrina mos xerrava des temps, es padrí de fora vila, els meus pares de sa feina i jo de s'escola. Aviat però, callàvem per poder escoltar s'informatiu.

Record especialment un d'aquests sopars. Menjàvem ous amb tomàtiga (boníssim) i teníem «La primera» en marxa perquè feien el programa «Gente», llavors el preferit de sa padrina. Una de les notícies va ser la d'un assassinat d'una al-lota jove. La presentadora explicà que el mòbil del crim havia estat un robatori. Acte seguit, sa padrina va alçar es cap, una cella i ses mans i va dir:

—Déu mevet del Sant Gloriós! No sé on arribarem. Vos pareix que per robar un mòbil han de matar una persona?

ENCARA REIM.

(P.S.: totalment verídic).

No és gratuit ni casual que l'alumna hi posi en relleu i hi consigni en majúscules la reacció dels pares i la seva pròpia ni que es preocupi de deixar-hi prou clar, a manera de post scriptum, que l'episodi és «totalment verídic». L'eficàcia humorística del relat, certament, es basa en un joc de paraules —en català, mòbil es pot referir tant a la 'motivació que empeny algú a cometre un crim' com ser la forma abreviada i més comunament usada de 'telèfon mòbil'-, però aquest relat no té la disposició retòrica pròpia dels acudits verbals. El que hi provoca les rialles dels circumstants és la mala interpretació que l'àvia fa de les paraules de la presentadora i no cap disposició retòrica determinada i voluntària del seu comentari a la notícia. Es tracta, de fet, d'un exemple d'humor involuntari, que, segons Attardo i Chabanne (I992: I7I), «is uttered without being controlled and intended for such purpose; this is the result of a problem in the locutor's control over his/her speech».

Un cas ben diferent, en canvi, és el del text que va aportar Maria Antònia Roig, que jo no dubtaria a considerar com a exemple d'acudit verbal:

Van pujar al Puig Gros dos «curiablanquers», pare i fill. Quan eren al punt més alt s'assegueren a berenar; feia un dia clar i es veia fins i tot Cabrera. Mentre parlaven, el fill li demanà al pare:

—Mon pare, què pagaríeu per tal que tot el que veiem fos nostre?

I el pare respon:

-Ben segur que molta contribució.

Si hi aplicam el model d'anàlisi que proposen Attardo et alii (I994) per a l'estudi i la classificació dels acudits, l'oració «què pagaríeu» hi funciona com a connector lexicalitzat, això és, un segment de text que pot interpretar-se de dues maneres. El sintagma «molta contribució» hi és el disjuntor que provoca que el receptor del relat hagi de reactualitzar semànticament el connector per mitjà d'una reassignació de sentit a l'oració: en principi, el receptor interpreta la pregunta del fill 
com 'quina quantitat de diners pagaríeu per comprar'; la resposta del pare, però, l'obliga a reinterpretar-la com 'quants d'impostos hauríeu de pagar per tenir'. ${ }^{8}$

La tercera aportació que vull comentar és la que va fer Marta Cabot, un altre relat d'experiència personal que, en aquest cas, té connexions amb la llegenda urbana:

Un dia, no fa molt de temps, vaig anar a fer la compra a Alcampo. Vaig aparcar al pàrquing subterrani i vaig anar a fer la compra. Tot va anar bé fins quan va arribar l'hora de posar la compra dins el cotxe, perquè va resultar que no recordava on havia aparcat...

Em va semblar estar una eternitat cercant el cotxe però a la fi el vaig veure. Una vegada vaig ser al cotxe, el vaig intentar obrir i no s'obria de cap de les maneres, ja no em podia passar res més.

Després d'intentar-ho un parell de vegades vaig mirar bé el cotxe i resulta que era un cotxe exactament igual que el meu, però no era el meu. El més graciós va ser que el meu cotxe estava just devora aquell, però clar, abans de trobar el meu, tota persona que passava pel meu costat, persona que mirava què coi feia, quin desastre! Amb això em va quedar clar que la meva mare té tota la raó del món quan diu que sóc molt despistada.

Es tracta del relat d'una situació que no ens pot ser desconeguda als que conduïm cotxe. Qui no s'ha perdut mai en un aparcament d'una gran superfície comercial? Qui no ha confós mai el cotxe d'algú altre amb el propi? Però el report que fa aquesta alumna de la seva experiència personal té molt a veure també amb el gènere de la llegenda contemporània o urbana: una dona sola, un gran centre comercial, un aparcament subterrani on és fàcil desorientar-se, dos cotxes idèntics i una situació compromesa. De fet, la primera secció de l'índex de tipus de llegendes urbanes que proposa Brunvand (I993: 325-329) duu per títol «Legends about Automobiles». En difereix, però, en un aspecte essencial. I és que hi falta el final imprevist, desconcertant i aterridor que defineix aquest subgènere llegendari (Shojaei 20II). I, encara, en un altre de no tan obvi, però més important i que és probable que sigui el que marca la frontera entre el relat d'experiència personal -que podríem dir que té un abast i un impacte limitats en termes de difusió- i la llegenda, que és susceptible de difondre's gairebé indefinidament: aquest és un relat d'experiència, però no el relat d'una experiència. La distinció em sembla molt pertinent i la prenc d'Abrahams (2005: 76):

Just as we make a distinction between experience, referring to the flow of life through the activities of individuals, and an experience, a happening which is sufficiently removed from the evereyday flow of life that it may be used as a point of reference for later discussion, so too we distinguish among various kinds of retold experiences in terms of how typical they are and how fully they carry important cultural messages.

\footnotetext{
8. Aquesta mateixa disposició del material lingüístic és la que trobam en el text que va aportar Miquel Joan Gomila com a exemple d'acudit: «Això és un pagès que se'n va a un ple de l'Ajuntament de Palma. Té necessitat de fer aigües majors i surt a l'olivera que hi ha davant de Cort. Se li acosta un Guàrdia Civil i li diu: —N'hi haurem de donar part, al batlle! I el foraviler li diu: -Per jo li podem donar tot sencer!»
} 


\section{A manera de conclusió}

L'anècdota, doncs, com a gènere folklòric autònom, certament té punts de contacte amb la llegenda - el relat pot suscitar debat o generar reserves sobre la possibilitat que els fets que s'hi conten o les paraules que s'hi reporten puguin ser verídics - i amb el relat sobre experiències reals — el relat es mou en el mode realista i pot revestir un to experiencial o testimonial-, però pens que el gènere amb el qual té unes afinitats més evidents és l'acudit: es tracta d'una mena de relats uniepisòdics que plantegen un conflicte narratiu que es resol verbalment i que tenen una manifestació perlocutiva característica, que pot anar des del somriure fins a la rialla estrepitosa. D'entrada, podria semblar que allò que distingeix un gènere de l'altre és la naturalesa del protagonista o dels protagonistes del relat: i és que la narració d'un mateix conflicte adopta la forma d'acudit o la d'anècdota si el protagonista és una persona real o una celebritat o si és simplement un personatge de ficció. Ja fa molts d'anys que Jaume Mascaró Danús em va explicar l'acudit següent, prou conegut:

Això era un que tornava a ca seva, gat com una sopa. Veu una dona pes carrer i li diu:

-¡Fea!

I ella li diu:

- ¡Borracho!

I ell contesta:

- Sí, pero mañana a mí se me habrá pasado...

Aquest mateix conflicte i la mateixa resolució verbal, aquest mateix diàleg, s'ha atribuït amb freqüència a Winston Churchill i a la parlamentària laborista Bessie Braddock i ha pres, doncs, el caràcter d'anècdota. Langworth (2008: 550) en recull aquesta versió: ${ }^{9}$

Bessie Braddock: Winston, you are drunk, and what's more you are disgustingly drunk.

Winston Churchill: Bessie, my dear, you are ugly, and what's more, you are disgustingly ugly. But tomorrow I shall be sober and you will still be disgustingly ugly.

Que el protagonista del relat sigui una persona real o una celebritat, però, no és el que realment defineix el gènere, perquè ja hem vist més amunt que hi ha celebritats que es converteixen en protagonistes d'acudits o de cicles d'acudits, més aviat. El que marca els límits entre els dos gèneres és, en el fons, el propòsit amb què el locutor actualitza i enuncia l'argument narratiu. L'acudit té sempre una finalitat ridiculitzadora. L'anècdota, en canvi, té sempre un propòsit admiratiu o laudatori amb qui té la capacitat de resposta i l'agilitat mental i verbal necessàries per proposar la solució verbal enginyosa que escau millor a cada situació

9. Per a altres versions d'aquesta història, vegeu: $<$ http://quoteinvestigator.com/20II/o8/I7/ sober-tomorrow $>$. Hi són ben reveladors dels dubtes que pot suscitar el relat anecdòtic els comentaris que hi fan dos internautes, que qüestionen l'atribució de l'anècdota a Churchill en aquests termes: segons un, la rèplica «has an un-Churchillian ring» $\mathrm{i}$ conté "superfluous words, and ends bathetically»; l'altre hi afegeix que "Churchill spoke in a much more subtle way which gave him his dry sense of humour» [consulta: I9.OI.I3]. 
conflictiva. I, en aquest sentit, proporciona al narrador i a l'auditori una mena de precedent d'autoritat amb vista a la resolució de la situació vivencial i comunicativa que la suscita.

\section{Referències bibliogràfiques}

ABRAHAMS, Roger D. (2005): Everyday Life: A Poetics of Vernacular Practices. Filadèlfia, Pennsylvània: University of Pennsylvania Press.

Allen, Barbara (1989) [1978]: «Personal Experience Narratives: Use and Meaning in Interaction». Dins Eliott ORING (ed.): Folk Groups and Folklore Genres: A Reader. Logan, Utah: Utah State University Press, p. 236-243.

AtTARdo, Salvatore; Jean-Charles ChABANNE (I992): «Jokes as text type». Humor núm. 5 I/2 (I992): I65-I76.

ATTARDo, Salvatore et alii (I994): «The linear organization of jokes: analysis of two thousand texts». Humor num. 7/I (I994): 27-54.

BLACHE, Martha (I999): «The Anecdote as a Symbolic Expression of the Social and Cultural Milieu of Journalists». Folklore núm. IIo (I999): 49-55.

BennetT, Gillian (I988): «Legend: Performance and truth». Dins Gillian BeNNETT; Paul SMITH (eds.): Monsters with Iron Teeth. Sheffield: Sheffield Academic Press, p. I3-36.

Brownlow, Louis (1960): The Anatomy of the Anecdote. Chicago, Illinois: The University of Chicago Press.

BRUNVAND, Jan Harold (I993): The Baby Train And Other Lusty Urban Legends. Nova York: W. W. Norton \& Company, Inc.

- (1998): The Study of American Folklore: An Introduction. Fourth Edition. Nova York: W. W. Norton \& Company, Inc.

Herman, David; Manfred Jahn; Marie-Laure RYAN (eds.) (2008): Routledge Encyclopedia of Narrative Theory. Londres: Routledge Ltd.

LANGWORTH, Richard (ed.) (2008): Churchill by Himself: The Definitive Collection of Quotations. Nova York: PublicAffairs.

Nicolaisen, W.F.H. (I997): «Anecdote». Dins Thomas A. Green (ed.): Folklore: An encyclopedia of beliefs, customs, tales, music, and art. Santa Barbara: ABC-CLIO, Inc., p. I7-I9.

ORIOL, Carme (2002): Introducció a l'etnopoètica. Valls: Cossetània Edicions.

Rosselló, Pere (I999): Els camins de la cançó: Vida i obra del P. Rafel Ginard Bauçà. Biblioteca Miquel dels Sants Oliver II. Barcelona: Publicacions de l'Abadia de Montserrat / Palma: Universitat de les Illes Balears.

STAHL, Sandra K. D. (I977): «The Oral Personal Narrative in Its Generic Context». Fabula núm. I8 (I977): I8-39.

ShojAeI, Christine (2OII): «The Contemporary Legend as a Cross-generic Genre». Fabula núm. 52 3/4 (2OII): 250-264.

TAYlOR, Archer (I970): «The Anecdote: A Neglected Genre». Dins Jerome MANDel; Bruce A. Rosenberg (eds.): Medieval Literature and Folklore Studies. New Brunswick/New Jersey: Rutgers University Press, p. 223-228. 
Jaume Guiscafrè Danús

Tèneze, Marie-Louise; Paul Delarue (†) (I976): Le conte populaire français. Tome troisème. París: G. P. Maisonneuve et Larose.

Thompson, Stith (I977) [I946]: The Folktale. Berkeley i Los Angeles: University of California Press.

- (I993): Motif-Index of Folk-Literature. Bloomington: Indiana University Press/ InteLex Corporation [cd-rom PC].

UTHER, Hans-Jörg (2004): The Types of International Folktales. 3 vols. Folklore Fellows' Communications 284-285-286. Hèlsinki: Suomalainen Tiedeakatemia. 
Reflexions a propòsit de l'«Anecdotari artanenc» de Rafel Ginard

\section{Annex}

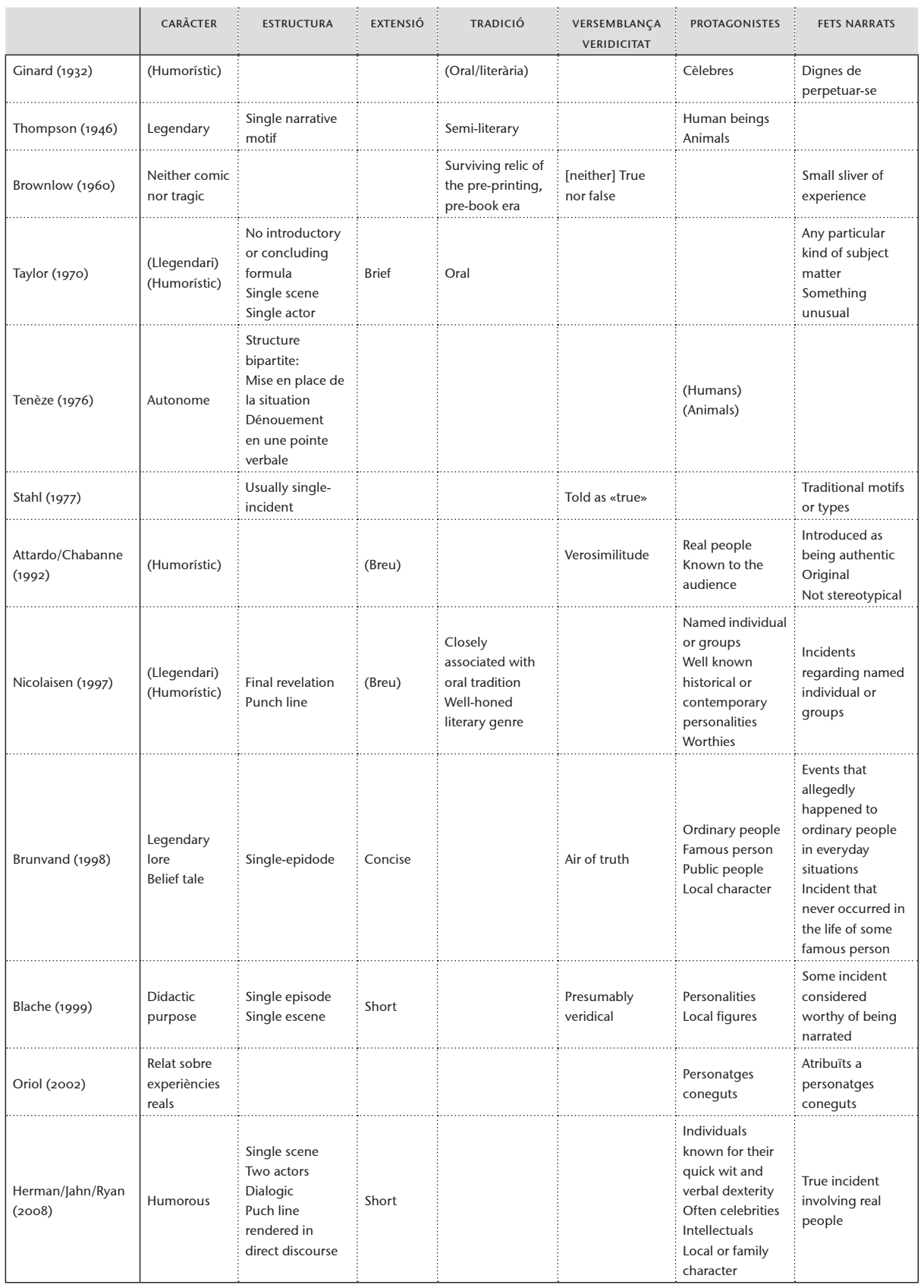

